„Bohemistyka” 2019, nr 3, ISSN 1642-9893

Dobrava MOLDANOVÁ

DOI: $10.14746 /$ bo.2019.3.1

Univerzita Jana Evangelisty Purkyně

\section{Románová reflexe 28. října 1918}

\section{(K. M. Čapek Chod, A. M. Tilschová, B. Benešová)}

Keywords: novels, K.M. Čapek Chod, A.M. Tilschová, B. Benešová, 28th October 1918, change of social and moral norm

Klíčová slova: romány, K. M. Čapek Chod, A. M. Tilschová, B. Benešová, 28. ř́ijen 1918, proměna společenských a mravních norem

\section{Abstract}

The study Reflection of the October in Czech novels analyses several novels that originated in the twentieths of the twentieth century. Their authors, K.M. Čapek Chod, A.M. Tilschová and B. Benešová, reflect the change of social climate during the war and immediately after it. They connect the rise of the new State, a democratic Republic, with the notion of liberation from empty social norms connected with the world before the war. Characters of these novels are undergoing a catharsis that liberates them and opens new perspectives of life for them.

Studie Románová reflexe 28. řína 1918 se zabývá několika českými romány, vzniklými ve 20. letech 20 . století, jejichž autoři, K.M. Čapek Chod, A.M. Tilschová a B. Benešová reflektují změnu společenského klimatu za války a bezprostředně po ní. Proměnu spojují nejen se změnou společenského zřízení, se vznikem demokratické republiky, ale především s představou osvobození se od společenských norem, spojených se světem před válkou. Postavy těchto románů procházejí katarzí, která je osvobozuje a otvírá jim nové životní perspektivy.

Prapory, jásot, na praporu prapor Srdce se v dálku rozletí.

Jak je to krásné překonati zápor a býti, růsti, stavěti!

(V. Dyk, Píseň noci 29. ř́lina)

Básníkova slova vyjadřují tehdy široce sdílené přesvědčení, že vznikem Československa v ř́íjnu roku 1918 čas resistence, odporu, negace skončil a nová doba svobodnému národu klade pozitivní cíle. Za- tímco poražené velmoci, Rakousko-Uhersko a Prusko, v jejichž geografickém středu ležely naše země, se zmítaly ve zmatcích a obtížně se vyrovnávaly s důsledky války, která zásadně změnila jejich pozici mezinárodní i situaci vnitřní, zde vládlo nadšení národa, který, jak zněla dobová fráze, ,trpěl 300 let pod cizáckým jhem” a teprve nyní se mu otevřel prostor, aby mohl rozvinout své síly, svobodně navázat na své ušlechtilé tradice, zaujmout místo mezi svobodnými a plnoprávnými národy. Atmosféra Prahy 1918 byla zcela jiná než atmosféra Vídně či Berlína a situace Čecha navracejícího se z války domů zcela jiná než vojáka vracejícího se do rozvráceného Rakouska a do poraženého Německa z Ruska. Navíc, Čechoslováci, díky svým zahraniční legiím, které bojovaly na straně Dohody v Rusku, ve Francii a v Itálii, patřili $\mathrm{k}$ vítězům velké války. Získaná svoboda měla být naplněna novým obsahem. To se objevuje i jako klíčové téma v próze. Má řadu podob $^{1}$.

Když pomineme Haškova Švejka jako specifické a svým způsobem ojedinělé ztvárnění válečné zkušenosti, jednu vrstvu tvoří díla, která vznikla z elementární, skoro se chce rríci předliterární potřeby vypsat se z toho, co člověk, dosud žijící v klidných mírových podmínkách, zažil za války. Sem patři především legionářská literatura, tematicky čerpající z dramatické historie československých dobrovolníků, z nichž se zformovaly v Rusku, ve Francii a v Itálii československé legie. Jejich autoři jsou nejen renomovaní spisovatelé, ale mnohdy i lidé bez literární zkušenosti a snad i bez předchozí literární ambice. Jsou to vesměs románové kroniky, často i polodokumentární prózy. ${ }^{2} \mathrm{Na}$ druhém pólu stojí skupina románů starších autorů, kteří problém války pojali jako problém zásadního morálního otřesu, vedoucího $\mathrm{k}$ restrukturalizaci žebříčku hodnot jednotlivce i národního společenství. Oni nezažili hrůzy fronty, zato plně prožili léta stísněných poměrů a poli-

Široký obraz této problematiky podává sborník Karel Poláček a obraz první světové války v české literatuře 2007; též in Obraz válek a konfliktů... 2015.

${ }^{2}$ Legionářská literatura, odsouzená dvěma totalitami k zapomnění, se v poslední době dostává znovu do centra pozornosti, vedle citovaného poláčkovského sborníku, kde je jí věnovaný celý oddíl, viz též Moldanová 2016. 
tických persekucí v zázemí a válku a 28. říjen 1918 chápali jako jakousi zkoušku ohněm, jíž prošli jedinci, ale i celé národní společenství. Toto pojetí se neobjevilo naráz a náhodou, ale je vyvrcholením určitého názorového proudu, který se krystalizoval už za války.

Válečná léta byla léty, kdy se definitivně měnil vztah Čechů k monarchii, persekuce s válkou spojené vedly k vyostření protirakouských postojů a spontánnímu nárůstu vlasteneckých projevů. Literatura se obrací k prožitku domova jako významné hodnotě, která dobře rezonuje mezi čtenáři. Svědčí o tom ohlasy děl, jako bylo Jiráskovo Temno (1915) či Šrámkovo Léto (1915), které se na první pohled nedotýkaly aktuálních problémů, ale vyjadřovaly zjitřenou vnímavost $\mathrm{k}$ hodnotám tradice. Podobně lyriku s tématem domova psali za války i autoři, kteří patřili k okruhu moderny či k předválečným anarchistům (Otakar Theer, Antonín Sova, Karel Toman), tedy k uskupením s výrazně antitradicionalistickými postoji, pro něž vlastenectví bylo původně spíš předmětem přezírání či dokonce posměchu.

K vrcholům prózy napsané za války patřily romány Karla Matěje Čapka Choda Turbína (1916) a Antonín Vondrejc (dva svazky, 1917-1918), Boženy Benešové Člověk (dva svazky, 1919-1920), Anny Marie Tilschové Stará rodina (1916) a Synové (1918) a Ivana Olbrachta Žalář nejtemnéjší (1916) a Podivné prátelství herce Jesenia (1919). Každý z těchto románů představuje svým způsobem experiment. Autoři rozrušují strukturu monografického románu, jaký vypracoval realismus a naturalismus, usilují o postižení komplikovaných společenských vazeb a sociálních prostředí a zároveň se pokoušejí proniknout hlouběji do vnitřního světa svých hrdinů. Groteskní obrázek předválečné Prahy u Čapka Choda nejen evokuje předválečnou idylu patriarchálního kapitalismu, ale také postihuje symptomy krize, jíž společnost procházela, nebo lépe symptomy proměny, která stojí před jeho hrdiny. Mísení společenských vrstev, rozpad tradičních rodin a znejišstování životních jistot je spojeno s nástupem nové dravé a bezpředsudečné generace, která se dere o své místo na slunci - to je vlastní téma těchto románů. I pro Tilschovou je zánik světa „starých rodin", $\mathrm{v}$ nichž panuje řád $\mathrm{z}$ jejího pohledu rigidní, tématem jejích prvních románů.
Pro Benešovou se stává ústředním problémem románu Člověk otázka po smyslu života: její hrdina, geniální hudební skladatel, který vidí smysl svého života $\mathrm{v}$ napsání symfonie, prochází komplikovanými životními peripetiemi, které mu v tom brání. Svého cíle nedosáhne: zahyne, když se vrhne do hořícího domu, aby zachránil dívku, která byla symbolem jeho ponížení. Přesto ve chvíli smrti prožívá pocit životního naplnění. Benešová jeho příběh rozvíjí v několika paralelních vrstvách, ke svému hrdinovi přidává postavy, které jsou jeho protivníky ale i dvojníky, stejně jako on hledající životní zakotvení, každý jiné a jinak. Podobné otázky si klade Šalda ve svém jediném románu Loutky i délníci Boži (1917). Olbrachtův román Žalář nejtemnější, zřejmě první moderní psychologický román v české literatuře poučený psychoanalýzou ${ }^{3}$, je soustředěn na př́běh jedince, který na vrcholu svého úspěšného života oslepne. Jeho život se hroutí, kariéra je v troskách, rozpadá se i jeho manželství. V okamžiku, kdy přijme svůj osud a najde východisko v altruistické práci pro druhé, objevuje nový smysl života. V románě Podivné přátelství herce Jesenia jsou konfrontovány dva různé životní postoje, jeho dva protagonisté, Jan Jesenius a Jiří Veselý, jsou jacísi dvojníci a zároveň protichůdci, kteří, každý po svém, hledají smysl života.

Válka obnažila mravní krizi a postavila před umělce otázky: jaký je vztah jedince k celku, umělce ke společnosti. Řešení, k němuž autoři, o kterých uvažujeme, nacházejí, je v akcentu na „obyčejný” lidský čin, na obětování osobního cíle ve prospěch vyššího příkazu, plynoucího z pocitu lidské sounáležitosti. V tom smyslu se autoři vlastně rozcházejí s individualistickým konceptem, který si vytkla jako heslo Moderna, odkojená Nitschem a Schopenhauerem. Umělec, výjimečný člověk, schopný jedinečných výkonů, není vyvázán z obecně platných etických norem. Pod tlakem mimořádných okolností rezignuje na jakási vágní privilegia, která ho stavěla nad ostatní „obyčejné” lidi. Válečná zkušenost, kdy smrt si nevybírá své oběti, ale smete stejně člověka mimořádně nadaného i prost'áčka, $v$ tom jistě hrála svou roli.

\footnotetext{
${ }^{3}$ Tento názor vyslovil např. Jiří Opelík (1992)
} 
Na sklonku války se objevovala snaha vytvářet jakési společné kulturní platformy napříč generacemi a skupinami, jejímž výrazem bylo jak provolání českých spisovatelů z května 1917, podepsané umělci nejrůznějšího zaměření, tak napřr. založení časopisu „Lípa”4 , který poskytl prostor umělcům všech generací, od stařičkého Josefa Holečka po začínajícího Richarda Weinera. Tato vlna jakéhosi národního sjednocení a souznění byla krátká. Po vzniku republiky ji rychle překryl dravý nástup nových idejí spojených s ozvuky revolučních vln, které zasáhly východní, ale i střední Evropu, a s avantgardními proudy, k nimž se hlásila zejména nejmladší generace. Pro starší autory, kterým bylo v té době okolo padesátky, však toto téma zůstalo aktuální ještě do konce 20. let. Otázka, čím novou svobodu naplnit, na jakých základech budovat nový stát a jaké úkoly stojí před spisovateli, byla pro ně stále aktuální. Svoboda byla spojována nejen a ne přednostně s vnějším osvobozením, ale zejména s mravní očistou, s mravní obrodou, která byla vnímána jako základní idea nového státu.

Karel Matěj Čapek Chod, nejstarší z autorů, jimž chceme věnovat pozornost, vstoupil do literatury na počátku devadesátých let. Jeho první práce, kterými př́liš nezaujal, zejména Nejzápadnější Slovan (1893), sice souzněly se snahou jeho mladších vrstevníků o proměnu románové formy, ale jeho způsob vidění světa jako bizarního theatru mundi se od jejich vidění lišil. Podobně jako romány Viléma Mrštíka, F.X. Svobody či Růženy Svobodové z té doby byl jeho Nejzápadnější Slovan jednou z podob českého románu ztracených iluzí (o tom podrobněji Moldanová 2014). Na rozdíl od nich ale Čapek Chod příběh svého hrdiny neviděl jako osobní tragédii citlivého jedince, způsobenou konfliktem s lhostejným okolím, ale jako řetěz tragikomických náhod, ústících do závěru, v němž se ideály, které mladého hrdinu přivedly na cestu za úspěchem a štěstím, změnily ve výsměšný škleb. Svoboda, Mrštík i Svobodová do svých postav vložili kus své osobní i generační historie, Čapek Chod si zachovává od svého hrdiny až ironický odstup. Vztah kritiky k němu se mění až po vydání Kašpara

4 Časopis „Lípa” vycházel v létech 1917-1920. Založila ho a do své mrti 1. 1. 1920 redigovala Růžena Svobodová, poslední ročník pak redigovala Božena Benešová
Léna mstitele (1908), který byl s respektem přijat např. F.X. Šaldou (1953), a zejména po úspěchu Antonína Vondrejce a Turbiny, i když nelze říci, že se podstatně mění Čapkova poetika.

Tradičně bývá Čapek Chod vykládán v kontextu českého naturalismu, dokonce, podle Bedřicha Václavka, představuje jeho vrchol (Václavek 1974, s. 41-43). I další syntetická díla sdílejí tento názor. Naznačují, čím Čapek Chod naplňuje představu o naturalismu: zobrazuje člověka jako pouhou bezmocnou loutku jednostranně determinovanou vnějšími okolnostmi, jako produkt svého prostředí ${ }^{5}$. Čapek Chod své zařazení mezi naturalisty indikoval: užil tento termín v označení několika svých prací, poprvé v novele Nejzápadnějši Slovan, kde první část př́běhu označil za romantickou, druhu za realistickou a třetí za naturalistickou. V novele Zpověd' naturalistova (Nové patero, 2010) líčí př́iběh lásky mladého muže, který je plný ironických nedorozumění. Pygmalionské snahy zamilovaného mladíka končí tragicky. V obou př́padech však nejde o to, že by se titulem svých prací Čapek Chod k naturalismu hlásil, akceptoval jeho metodu, naturalistickou metodu ,lidského přírodopisu”, naopak, jde tu o ironizující odstup od jeho principů. Čapkovi hrdinové jsou obětí nikoli svého prostředí, ale svých iluzí, svého naivního idealismu, který naráží na realitu běžného života.

Změna názoru na dílo Karla Matěje Čapka Choda je myslím víc než vyzráním autora způsobena změnou dobového literárního paradigmatu. Mezi roky 1893, kdy vyšel Nejzápadnější Slovan, a rokem 1910, kdy se objevil Kašpar Lén, se objevily nové impulsy, zejména spojené s poetikou expresionismu. Přinesly výraznou změnu v pojetí románové struktury, především rozbití souvislé kompoziční linie realisticko-naturalistické prózy. Čteme-li v té době napsané romány Šrámkovy (nejen Střibrný vítr, 1910, ale zejména Křžovatky, 1913,

\footnotetext{
5 Tento názor lze číst v Přehledných dějinách J.V. Nováka a Arne Nováka (Praha 1922, s. 580-581), stejně jako v Prưvodci po dějinách české literatury autorů Josefa Hrabáka, Dušana Jeřábka a Zdeňky Tiché (Praha 1976, s. 322-383) i v akademických Dějinách české literatury IV (eds. Zdeněk Pešat a Eva Strohsová Victoria publishing, Praha 1995 s. 57-58). Širší pohled na Čapka Choda přineslo londýnské sympózium v roce 1984 (viz K.M. Čapek Chod... 1984).
} 
jsou z tohoto hlediska důležité), Benešové Člověka, Olbrachtovo Podivné prátelství herce Jesenia, sledujeme, že autoři, byt' různě a různými prostředky, směrují $\mathrm{k}$ rozvolnění struktury románového tělesa, posilují význam epizod a epizodických postav, které hrají roli jistého korektivu a někdy prímo alter ega ústřední postavy a směřují k postižení mnohosti života řetězcem volně řazených epizod či př́mo paralelních př́běhů (o tom podrobněji Moldanová 1993, s. 43-63).

Poválečné romány Karla Matěje Čapka Choda Jindrové (1921) a dilogie Vilém Rozkoč (1923) a Řešany (1927) v tomto směru nepřinášejí mnoho nového. Je tu stále ústř̌ední příběh rozvíjený množstvím epizod a odboček, barvitými detaily a výraznými reáliemi. Šalda, který na Čapka Choda reagoval až podrážděně, mluví s despektem o „zábavném kinu” či „slepenci”" Čapek svou metodu hájí:

Bude mi zazlíváno přelidnění mé knihy, bude ukazováno na její délku [...] ze strany těch, kdož na románu vymáhají poslušnost zákonu dramatické kompozice anebo klasické novely. Ačkoli jsem z toho všeho byl mnohokráte kárán, nikdy nevzdám se nejmohutnější možnosti velkého románu o pražském prostředí, vyčerpati totiž proud pražského života v určitém období až na samo dno. [...] Mnohost života jest mi svrchovaným skladebním př́kazem (Čapek Chod 1936, s. 358-359).

V Jindrech ožívá v mnoha detailech Praha počátku 20. století. Kolorit idylického města podtrhují periferie plné drsného a intenzivního života. Sledujeme př́běh otce a syna, z nichž starší ztělesňuje typ pražského dandyho formovaného poklidnou atmosférou předválečné Prahy bohatých vrstev, a mladšího, který vyrostl jako otloukané nemanželské dítě v nejchudší pražské čtvrti. Jindra starší je zámožný bonviván, který se vrací po krachu manželství do Prahy ze světa a stává se významnou figurkou jejího bohémského prostředí; jeho nemanželský syn má zcela jinou životní zkušenost. Jejich setkání a posléze soužití není idylické: mladší Jindra se dívá na otcův svět $\mathrm{s}$ trochou moralistického odstupu, zároveň je jím přitahován: díky otci vystudu-

${ }^{6}$ Šalda zaútočil na Čapka Choda statěmi Posledni K. M. Čapek Chod (Kritika 1, s. 250-256, knižně in Kritické projevy 12, Československý spisovatel 1959, s. 250-255) a Kritické přispěvky k poznání Čapka Choda (,Kritika” 2, s. 41-45, knižně in Kritické projevy 13, Československý spisovatel 1963, s. 101-116). je medicínu a začíná úspěšnou kariéru očního lékaře a badatele. Válečné události nejen rozvrátí jejich životy (syn narukuje, následky úrazu přijde o zrak, jeho děvče se stane milenkou Jindry staršího a čeká s ním dítě), ale také jsou impulsem $\mathrm{k}$ přehodnocení životních postojů obou protagonistů. Předválečná idyla se nemůže vrátit, nejen pro fatální zranění Jindry mladšího, nejen pro zhroucení vztahu otce a syna, ale i pro to, že ve světle válečných událostí se mění i pohled na předválečné osobní problémy, které determinovaly jejich životy.

Ještě výrazněji je to zřejmé v rozkočovské dilogii. I zde př́iběh začíná před válkou. Vilém Rozkoč je bohém a nadaný sochař, který ale ke svému talentu nedostal dávku morálního cítění. Bez zábran, vlastně jako vtip, zadá do soutěže o pomník významnému rodáku v Řešanech návrh, který je plagiátem Rodinova Myslitele. Soutěž díky nekompetentní a neinformované porotě vyhraje a - trochu s rozpaky - realizuje svůj návrh. Pomník vyvolá v odborných kruzích skandál, který Rozkoče málem zničí. Válečná zkušenost z fronty (charakteristicky vstoupí do legií) lehkomyslného a cynického bohéma přetvoří. Po návratu $z$ války se rozhodne sochu zničit. Situace, která tím vznikne, je komplikovaná. Socha je majetkem Řešan, které ji zaplatily a jejichž radní nejsou vnímaví k Rozkočově problému. Jeho pověst jako seriózního umělce je zničena, jeho osobní život je v troskách. Jeho vưle změnit život naráží na nedůvěru.

Oba př́iběhy nekončí jednoduchým happy-endem, ostatně jako i předchozí romány Čapka Choda. Přesto se v jejich závěru objevuje jakési světlo naděje, spojené s přerodem hrdinů. Prošli těžkými zkouškami, které je pochroumaly, a stojí v životě s jasným odhodláním žít jinak, odpovědněji, mravněji, byt' si uvědomují, jak těžké to bude. Tento moment morálního přerodu hrdiny, který je ve zmíněných románech naznačený, je v kontextu tvorby Čapka Choda neobvyklý, jedná se totiž o autora, který zachycoval v širokém záběru empirii lidského života, ale vyhýbal se filosofickému či ideologickému zobecnění.

Na rozdíl od toho se poválečné romány dvou spisovatelek, Haldy (1927) Anny Marie Tilschové a trilogie Úder (1926), Podzemni plameny (1929) a Tragická duha (1933) Boženy Benešové, k tématu mravní obrody jedince i společnosti soustřed'ují. Obě autorky, které 
debutovaly před válkou, v době vzniku jmenovaných děl patřily už ke starší generaci, Tilschová, narozená 1873, vydala Haldy ve svých 53 letech a Benešová, narozená v témže roce, pracovala na trilogii mezi 54. a 61. rokem věku. Obě patřily k mezigeneračním zjevům, mladší než autoři vstupující do literatury v 90. letech 19. století a starší než skupina autorů z okruhu anarchistů, hlásící se ke slovu na počátku 20. století. Jejich pohled na svět byl bližší těm starším, s těmi mladšími je pojila data jejich literárních debutů: obě své první knížky vydaly poměrně pozdě. Patřily $\mathrm{k}$ různým kulturním okruhům tehdejší Prahy. Tilschová se pohybovala, díky svému původu i sňatku, ve společnosti univerzitních intelektuálů a významných výtvarných umělců, pro Benešovou, která vyrostla $v$ prostředí malého moravského města, byl určující vztah k Šaldovu okruhu, s nímž se sblížila na počátku 20. století a který přetrval až do její smrti v roce 1936.

Jejich poetika se začala formovat v doteku s poetikou doznívajícího naturalismu a prvními vlnami expresionistického vidění světa, které se projevilo v postupném opouštění kompozičního schématu monografického románu, ve volbě postav (mám tu na mysli frekvenci zvláštních, jakoby dvojlomných charakterů u Benešové) a v akcentu na tragikomické a groteskní stránky života. Pro obě píšící ženy navíc bylo příznačné, že se odpoutávaly od ustáleného schématu, ženského příběhu", opouštěly svět křehkých hrdinek, trpících nepochopením i neschopností svůj život nezávisle a plně prožít. V jejich tvorbě se objevovaly víc než u jejich předchůdkyň otázky osobní morálky, témata odpovědnosti člověka za vlastní skutky, otázky viny a trestu i možnosti odpuštění. Jejich svět, svět jejich děl, nebyl parciálním ženským světem v tom smyslu, jak vidíme u autorek starších, ale světem úplným, celistvým (podrobněji viz Moldanová 2011). Otázky, které kladly, byly určeny jak mužům, tak ženám. Každá z nich - každá trochu jinak - zachycovaly svět v krizi, vnitřně rozpolcený, $v$ němž jsou rozkolísané základní společenské normy. Analyzovaly s překvapivou mírou odstupu i se skepsí dosud nedotčená tabu ,posvátných” rodinných vztahů i nepřekonatelnost sociálních bariér.

Válečné události uspíšily jejich rozchod s individualistickým konceptem 90 . let, který byl pro formování intelektuálního světa zejména
Benešové výchozím. Projevilo se to už v dvoudílném románu Člověk (1919, 1920), který vznikal za války. Román je složitou a bohatě zalidněnou strukturou, prolíná se tu několik paralelních př́íběhů, jejichž protagonisté představují jakousi oponenturu $\mathrm{k}$ postavě hudebního skladatele Cyrila Trojuše. Závěr románu staví nad jedinečnost tvůrčího činu etické normy, které umělce, stejně jako kteréhokoli člověka, váží k jeho rodině a celému lidskému společenství. Benešová ve složitě větveném příběhu umělce hledajícího smysl svého života v práci tu nadřadila povinnost k lidskému společenství, prostý skutek lidskosti nad výlučnost jedinečného geniálního umělce. Zkušenost války, která si nevybírala oběti a $\mathrm{v}$ níž náhodně a beze smyslu hynuli stejně géniové jako lidé sotva průměrní, byla zřejmě impulsem k takovémuto vidění světa. Závěr (mimořádný umělec obětoval svůj život, aby zachránil z hořícího domu dítě a touto obětí dovršil svůj život, jehož smysl viděl až dosud v napsání vrcholného uměleckého díla) vyprovokoval k polemické poznámce F. X. Šaldu:

Cyril Trojuš touží vykonat „malý lidský čin” spíš než stvořit své vrcholné dílo. Ale což toto dílo - není to dílo také lidský čin? A což není podmíněn tento čin dlouhou a dlouhou prací, vytrvalým a neslábnoucím úsilím dní a dní a nocí a nocí? Mám pochyby zda vrchol mravnosti leží v sebeobětování, v obětování svých nejvyšších možností? (Šalda 1936, s. 270-271).

Podobně jako polemika s individualistickým chápáním světa vyznívá i dvojromán Tilschové Stará rodina (1916) a Synové (1918), kde proti tomuto individualistickému konceptu spojenému s životní filosofií starší generace klade důraz na elementární lidské vazby, pocit sounáležitosti s lidmi, kteří člověka obklopují, na schopnost prožívat hluboké city, probouzející se v generaci synů, kteří se již necítí vázáni otcovskou autoritou, společenskými zvyklosti a hledají si - každý jinak - svou cestu životem. Pozoruhodné je, že jak Stará rodina, tak Synové jsou výrazně mužským románem (i v Člověku jsou ženské postavy pasívní a proti mužským upozaděné), ženské postavy jsou tu v druhém plánu, nemají svůj vlastní osud, vstupují do př́iběhu prostřednictvím mužů. Ještě výrazněji je tato proměna akcentovaná v dílech, která bezprostředně reflektují válečné události. Ta vznikala s přibližně desetiletým odstupem od války, tedy v době, kdy nadšení z konce vál- 
ky a vyhlášení samostatné Československé republiky utichalo a nový stát začínal prožívat své první složité období.

Tilschové Haldy se v mnoha ohledech vymykají z tematického rámce dosavadní i pozdější tvorby této autorky, čerpající náměty z prostředí pražské buržoasie a intelektuální a kulturní elity, tedy z prostředí, ve kterém se celý život pohybovala. Zasadila je do válečného Ostravska, do prostředí velkých průmyslových podniků, ale také do dělnických čtvrtí, a své hrdiny našla mezi hutníky a horníky, v prostředí, kde válečnou mizérii již zvyšovali ket'asi ${ }^{7}$ a vojenský režim na šachtách a v hutích. Je to román zázemí, zázemí neklidného a o nic méně dramatického než fronta. Tak jako v Zolově slavném Germina$l u$, i zde stojí proti sobě svět proletářủ a jejich zbídačelých rodin a svět panstva, úředníků, ale i válečných zbohatlíků, lhostejných $\mathrm{k}$ jejich bídě. Sociální konflikt je tu ještě zvýrazněn válečnou situací. Př́iběhy jednotlivých postav či skupin postav se odehrávají paralelně vedle sebe, jen místy se prolínají. Podobně jako v Germinalu, kde ústřední postavou je dělnický předák Étien Lantier, se postupně do popředí dostává postava hutníka Chalupy, který vyrůstá nejen v dělnického vůdce, ale je ztělesněním nadějí, které zbídačelí dělníci vkládají do konce války a vzniku republiky, o níž věřili, že bude garantovat nové sociální poměry a zajistí sociální spravedlnost. V kontextu tvorby Tilschové ale i českého románu té doby - je poměrně nové použití polyfonní metody, tedy budování románu $\mathrm{z}$ několika paralelních a rovnocenných př́běhů spojených se skupinami postav různého sociálního postavení. Náběh k tomu je zřejmý už ve Staré rodině a v Synech, zde je využita důsledně. Haldy nemají jednu ústřední postavu a jeden ústřední příběh, vytvářejí mozaiku individuálních př́běhů. Tato metoda velmi dobře posloužila záměru podat obraz sociálního neklidu válečného Ostravska podrobeného vojenskému režimu, konfrontovat různé postoje dané sociálním statutem postav i jejich rolí ve velkém válečném dění.

Proti Zolově románu (jeho př́klad nelze od Hald odmyslet) se Tilschová soustřed'uje víc na ženské postavy. I když „,velký př́iběh romá-

${ }^{7}$ Slovo ket’as je možná pro mladší čtenáře nesrozumitelné. Pro stejný fenomén za 2. světové války bylo slovo šmelinár̆ a za totality nejspíš vexlák. nu", př́iběh spojený s válečnými událostmi, nesou postavy mužské, život dílu vtiskují př́iběhy žen a dívek, momentky z jejich každodennosti, na nichž víc než na příbězích mužů vystupuje do popředí karneval otřesné bídy i morálního rozkladu válečných let. Čteme tu př́běhy zneužívaných proletářských dívek, tragických dělnických matek i záletných paniček z vyšší společnosti. Jedny bojují každodenní boj o přežití, druhé žijí v jakési zlaté kleci, kam nedoléhá nic $\mathrm{z}$ bouří doby a kde se odehrávají jen nicotné románky manželských nevěr. Galerie mužských postav je chudší, ovšem ne co do počtu, ale co do propracování. Vedle ket’asů a zbohatlíků se tu postupně vynořuje až v závěru románu výrazněji působící dělník Chalupa, který se nakonec stává mluvčím revolučního národního výboru, vyhlašujícího vznik republiky. Mírný a zdánlivě měkký Chalupa vlastně není aktérem dění, je jakousi zosobněnou ideou českého dělníka, k jehož atributům patří „holubičí povaha", a jeho rozhodné vystoupení román dovršuje nikoli z logiky vyprávěných př́běhů, ale jako demonstrace autorčiny vize, jako ztělesnění její potřeby drásavé příběhy uzavřít jakousi optimistickou vizí.

Jak vypadá obraz válečného zázemí u Boženy Benešové? Především rozsah trilogie výrazně přesahuje Haldy a poskytuje autorce podstatně větší prostor. Opět, jako v románu Člověk, se jedná o polyfonní strukturu, kde se jednotlivá dějová pásma, vázaná na různá sociální prostředí, prostupují, jsou budována jako paralelní a vlastně rovnocenné a samostatné př́iběhy nazírající základní téma $\mathrm{z}$ různých stran a v různých souvislostech. Tím tématem je proměna české společnosti i jedinců za války, znejistění tradičních hodnot a hledání nového životního obsahu. V centru těchto příběhů jsou ženské postavy, mladé dívky i zralé ženy, hledající ve zmatcích válečné doby morální i citové zakotvení: maloměstská slečinka „,z dobré rodiny”, která se za dramatických okolností odtrhne od rodinného zázemí, hraběnka snící o majorátu v době soumraku aristokracie, děvče z pražské hospody, dravě se deroucí „do lepších kruhů”. Tuto galerii doplňují lékařka, jejímž prostřednictvím vstupujeme do světa pražských intelektuálů, ale také protirakouské „mafie” a podnikavá hospodská, která dokáže v těžké době profitovat na bídě a neštěstí - než ji samu neštěstí v podobě synovy smrti dostihne. 
První svazek trilogie, román Úder, jako by prodlužoval tematickou linii povídkových knih mladé Boženy Benešové. Postavou, okolo které se točí jeho děj, je jedna $z$ dívek, o jakých psala před válkou. Alena je zhýčkaná slečinka $z$ bohaté rodiny, která se neškodně bouří proti konvencím určujícím její život. Nejprve je to jalová vzpoura dívky, která neví, co od života chtít, a vymezuje se jen negativně vưči svému rodinnému prostředí, ale i maloměstské scéně, na níž se pohybuje. Válečné události její vzpoưre dají nový náboj. Pocit, že se otřásá celý společenský systém, ve kterém vyrostla, jí dodá odvahu přiznat se k lásce k muži bez majetku, vzdělání a postavení. Matka zasáhne a nevhodného ženicha, který v jejích očích dceru jen kompromituje, udá: oznámí úřadům, že šîrí protirakouský manifest. Doufá, že dcera o „kriminálníka" nebude mít zájem. Je ovšem válka a platí jiné zákony. Mladík je zatčen a podle válečného práva odsouzen $\mathrm{k}$ smrti a bezodkladně popraven. Alena v přestrojení za komornou hraběnky Wallermünde opouští rodné město i vlast. Svět, který k ní byl dosud laskavý, se zhroutil, lidé, jejichž láska ji obklopovala, ji zradili.

Paralelně s př́iběhem Aleny autorka rozvijí příběh hraběnky Eleonory Wallermünde, která ztělesňuje oproti revoltující Aleně rigidní lpění na tradici. Spojuje svou budoucnost se setrváním starých pořádků, které válka $\mathrm{v}$ jejích očích jen dočasně rozkolísala. Centrem třetí dějové linie je vitální Zina, která si nepřipouští žádné problémy, prostě chce žít, prožívat svou lásku navzdory všemu. Neruší ji, že její rodiče na válečné bídě nemravně zbohatli, je imunní proti idealismu lidí, zapojených do protirakouského odboje, je spontánní ve svých láskách i nenávistech, bezohledná a strhující svou vitalitou. Děj se postupně přenáší z moravského městečka Rovinov do Prahy, do Vídně i do internacionálního prostředí šlechtických rodin. Každý z těchto dějových plánů má své epizodické odbočky a je bohatě zalidněn. Uvádí čtenáře do světa maloměstské smetánky, do šlechtického salonu, pražského kroužku vlasteneckých „,mafiánü ", konspirujících proti Rakousku, do hospody válečného zbohatlíka stejně jako do kanceláře vysokého rakouského byrokrata. Každé z těchto prostředí má svůj proud př́iběhů

${ }^{8}$ Domácí protirakouský odboj se označoval jako „mafie”. Byla to sít' vlastenců, kteří shromažd'ovali důležité informace a udržovali kontakt s exilovou skupinou okolo TGM. i své hrdiny, charakterizované vzhledem, jazykem i postoji. Podobně jako u Tilschové tu dominují ženské postavy, různorodé svým původem, temperamentem i osudem, každá jiná, z jiné společenské vrstvy, jinak válkou zasažená.

Při detailním pohledu nelze nepostřehnout, že trilogií prostupuje mnohohlasá diskuse o vztazích v rodině, zejména o vztazích mezi matkami a dcerami. Láska mateřská, mariánským kultem po staletí adorovaná, je zde podrobována důkladné, mnohostranné a nelítostné analýze. Není to jen vztah Aleny a její matky, který se osudově zamotá smrtí Slávka Přikryla, ale i další vztahy mezi matkami a jejich dětmi, vztahy na pohled obětavé a životodárné, ale v jádru sobecké. U Benešové matky nejen své děti milují, ale osobují si právo do jejich osudů zasahovat „pro jejich dobro”, manipulovat jimi, zneužívat je. Matka, nejen v evropské kultuře ztělesnění obětavosti a nesobeckosti, se tu objevuje v ambivalentní podobě: nejen jako bytost milovaná a milující, ale i jako bytost mrzačící, nejen obětavá, ale i sobecká. Zhroucení starého společenského řádu u Benešové vrhne i ostré světlo na tento elementární vztah a problematizuje jeho gloriolu. Válečná smršs' tedy nejen zničila Rakousko-Uhersko, rozbila jeho společenský systém, ale otevřela nové pohledy na dosud pevné struktury rodinného života, odkryla jeho mnohdy pokryteckou podobu a zásadně proměnila tu nejintimnější sféru lidského života: nejde už o vzpouru proti dohodnutým sňatkům a dalším konvencím omezujícím zejména ženský život, ale o zakotvení člověka v elementárních vztazích rodinných, které procházejí krizí a snad i jakousi katarzí.

Osobní př́běhy protagonistů trilogie ale také prostupuje mnohovrstevnatá diskuse o budoucnosti Rakousko-Uherska po vypuknutí války (situovaná charakteristicky do maloměstského hostince, který je jakýmsi Hyde Parkem, kde se potkávají lidé z různých společenských vrstev i různých názorů); znovu se vrací v jejím závěru, tentokrát v pražském intelektuálním prostředí. Je to jakási živě podaná encyklopedie názorů zachycující různorodé proudy, at' již spojené s radikálním odporem ke starým pořádkům, s tradičním slavjanofilstvím, intelektuálskými koncepcemi založenými na historickém povědomí, pragmatismem válečných zbohatlíkủ či názory „mafie”, tedy protira- 
kouského odboje spolupracujícího s masarykovským exilem, ale i svět šlechty. Tato rovina je spíš doménou mužských postav, jejichž galerie je v trilogii neméně pestrá jako galerie postav ženských.

V pozadí toho všeho se klene pro Benešovou kardinální otázka: jak se vypořádat s dvojznačnou a morálně nesnadnou pozicí Čecha a zároveň rakouského poddaného stovkami vazeb spojeného se státem, ve kterém žije, s pozicí člověka, který jedno říká a druhé cítí, který je zároveň občan a zároveň disident, ne-li velezrádce. Tehdy přece patř́ilo v intelektuálních kruzích $\mathrm{k}$ dobrému tónu sice nadávat na Rakousko, ale $\mathrm{v}$ běžných rodinách dávat dětem císařská a arcivévodská jména Josef, František, Rudolf, Otto, Karel, Ferdinand, Alžběta a usilovat o dobré postavení ve státních strukturách. Tehdy ještě nebyl na světě orwellovský doublething, ve kterém generace vyrostlé ve dvou totalitách žily, aniž by si př́liš uvědomovaly jeho morální pochybnost. Pro Benešovou je to zásadní problém, který si musí vyřešit vojáci na frontě, kteří sice př́sahali císaři, ale rozhodli se, jako její syn ${ }^{9}$, přidat k nepř́iteli, i lidé v zázemí, rozpolcení mezi pocit př́slušnosti ke svému národu a ke svému státu. Tento morální problém exponuje Benešová v několika polohách, nejvyostřeněji na své snad nejobjevnější figuře, př́zračné postavě policejního prezidenta Slavíka z Fliederheinu, která se vymyká tomu, jak bývá v naší literatuře běžně prezentován „rakušácký” byrokrat. Pro Benešovou, jak podotýkali pamětníci, bylo trvalým traumatem, že $\mathrm{v}$ základech nového státu ležela mnohonásobně porušená př́saha, něco, co považovala za neštastné předznamenání vznikajícího státu.

Nad závěrem románu se klene tragická duha smíření. Původní název třetího dílu Bílý den (odkazuje, snad ironicky, na Nerudovu báseň Jen dál) možná lépe vyjadřuje onu stř́zlivost, s níž autorka hledí na budoucnost. Není tu efektní konec jako u Tilschové, jen bílý den, ostré světlo všedního života ostře osvětlující čerstvé šrámy a jizvy. Vize budoucnosti, s níž hrdinové a hrdinky románu spojovali konec války, je překryta závěrečnou scénou, kde nad vším dominuje cit rodinné soudržnosti, pouto lidské odpovědnosti, schopnost odpuštění, ale také

${ }^{9}$ Roman Beneš, jediný syn Boženy Benešové, bojoval jako rakousko-uherský voják na italské frontě, po zajetí vstoupil do československých legií. rodící se láska snad přemáhající válečnou okoralost a zoufalství. To jsou pak zdroje nového života, v němž nebude, jak protagonisté románu začínají opatrně věrit, důležitý majetek, postavení, ale přirozené právo člověka na život $\mathrm{v}$ pravdě.

Závěry románů $\mathrm{A}$. M. Tilschové a Boženy Benešové jsou nicméně jejich citlivým místem: obě autorky spojují konec války s vlnou revolučních proměn, kterými prochází nejen česká společnost, ale prakticky celá Evropa. Opakovaně se v obou dílech připomíná ruská revoluce z roku 1917 jako inspirace a naděje na radikální řešení problémů, které válka obnažila. Román Haldy končí 14. říjnem 1918. Pro Tilschovou je vznik republiky, resp. události bezprostředně před jejím vyhlášení, signálem nového času: ustavením národního výboru v čele s dělníkem Chalupou končí nejen vojenský režim, který byl nad Ostravskem vyhlášen po dobu války, ale i vláda německo-židovské úřednické lobby nad ostravskými hutěmi a šachtami. I když Chalupa není výrazně radikální stoupenec např. ozbrojeného převzetí moci, jeho postoj je jednoznačný. Svoboda, vznik československého státu slibuje nastolení spravedlivých sociálních poměrů, nápravu křivd, potrestání zločinů, kterými románoví hrdinové trpěli. Pro Benešovou je problém složitější: i ona připomíná v promluvách a postojích svých hrdinů revoluční naladění Evropy, nicméně $\mathrm{v}$ závěru románu opouští rovinu společenských řešení. Směřuje do individuální a soukromé polohy, její revoluce se odehrává, řečeno s Masarykem, v hlavách a srdcích jednotlivců, v tom, jak se vyrovnávají s pocity vin a křivd, jak se probouzí jejich schopnost žít normální, mírový život, najít normální lidské zakotvení a znovu vybudovat svou válkou narušenou mravní integritu. Najednou mizí ona bezútěšná bezradnost, pocit prázdnoty, neschopnost naplnit život něčím smysluplným z doby před válkou. Krunýř konvencí se rozpadá.

Ani jedna $\mathrm{z}$ autorek $\mathrm{v}$ románech, které jsou ve středu naší pozornosti, nenahlíží za horizont roku 1918, nedovolí ničemu, aby rozostřilo onen pocit katarze spojený s koncem války, zpochybnilo onu očekávanou novou dobu, i když v polovině 20 . let, kdy na románech pracovaly, se leccos z ideálů a očekávání, které byly s 28 . říjnem spojeny, poněkud zkomplikovalo. Tilschová se $\mathrm{k}$ tématu první světové války už 
nevrátila, bylo pro ni uzavřené. Opět se ponořila do světa starých rodin a do pražského uměleckého a intelektuálního prostř̌edí. U Benešové (umírá krátce po dopsání trilogie v roce 1936) se ústřední téma trilogie objevuje v několika brilantních povídkách, kde promítá do generačního konfliktu syna a matky (povídka Není člověku dovoleno), babičky a vnučky (Don Pablo, don Pedro a Věra Lukášová, 1936) svou skepsi v nosnost tradičních rodinných hodnot. Vyprázdněnost rodinných pout, stejně jako téma zásadního rozdílu životních postojů lidí zakotvených $\mathrm{v}$ předválečných poměrech a lidí válkou bezprostředně dotčených, tak v její další tvorbě nemizí.

Oba románové projekty byly ve své době velmi dobře přijaty a opakovaně vycházely. Haldy vyšly celkem devětkrát. Po válce byla Tilschová jmenována národní umělkyní a sympatizující odkazy na ruskou revoluci v románě obsažené jí zajistily, že byla opakovaně vydávána i po únoru 1948. Benešová získala za Úder v roce 1927 státní cenu, celá trilogie do války vyšla čtyřikrát, po druhé světové válce, v polovině 50. let zásluhou Jiř́ho Honzíka vyšla ve Spisech Boženy Benešové popáté. $\mathrm{V}$ té době ovšem byla autorka již víc než deset let mrtvá. Vysvětlivky doprovázející toto vydání naznačují, že s přjetím díla byly problémy. Korigují ve smyslu dobové ideologie „,autorčinu poplatnost oficiálním buržoazním legendám”, týkající se např. interpretace úlohy legií v Rusku, stejně jako vlídnou poznámku na adresu amerického prezidenta Wilsona, kterou pronese v závěru trilogie jedna z postav (viz Benešová 1955, s. 241-242) ${ }^{10}$.

Podobné osudy měla i řada dalších děl reflektujících první světovou válku, jakoby její odkaz a ideály 28 . října bylo nutné v myslích

${ }^{10} \mathrm{~V}$ poznámce ke s. $142-143$ editor Jiří Honzík odkazuje na autorčinu formulaci: „Nemají- li dosud Němci Verdun a neplení-li Rakušáci dosud v Benátkách a zůstala-li Sibiř ušetřena teutonské hrabivosti, čí nesmrtelnou zásluhou to je?” a uvádí ji na „pravou míru” takto: „Zde Benešová v duchu oficiálních buržoasních legend přeceňuje význam účasti českých legií $\mathrm{v}$ závěrečné fázi první světové války a zároveň zcela nesprávně pojímá smysl vystoupení českých legií v tehdejším Rusku, nebot' tam už neměly úlohu hráze proti dobyvatelským choutkám Vilémova Německa, ale potlačovatele socialistické revoluce.” K formulaci „Kdesi ve světě je jakýsi Wilson, takový moudrý a spravedlivý pán" autor poznámek Benešovou opět opravuje: „Zde jde opět o nesprávné, oficiální pojetí Wilsona jako kladné a pokrokové posta- čtenářù „opravit” tak, aby se přerušila tradice, z níž republika vzešla a k níž patřilo i zamyšlení nad smyslem událostí z roku 1918 a jejich kritická reflexe. V popředí zájmu poúnorového režimu zůstala spíš ta díla, která ideály 28. ř́jna relativizovala, zdůrazňovala kriticismus $\mathrm{k}$ první republice a vyzdvihovala úlohu ruské revoluce při vzniku Československé republiky.

\section{Literatura}

B e n e š o vá B., 1955, Tragická duha. 5. vydání. Praha: Československý spisovatel. Č a p e k C ho d K.M., 1936, Doslov. In idem, Vilém Rozkoč, 3. vydání, Praha.

D y k V., 1922, Píseň noci 29. ř́jna. In idem, Poslední rok, Praha.

Karel Matěj Čapek Chod, 1984, red. Robert B. Pynsent. London: School of Slavonic and East European Studies University of London.

Karel Poláček a obraz prvni světové války v české literatuře, 2007, red. Erik Gilk, Jan Tydlitát, Rychnov nad Kněžnou.

K.M. Čapek Chod a Symposium - proceedings. 1984, London.

Obraz válek a konfliktů. V. kongres světové literárněvědné bohemistiky, 2015, red. Vít Schmarc a kol. Praha: Akropolis.

K r e j čí K., 1959, Anna Maria Tilschová. Praha: Československý spisovatel.

Mold a n ov á D., 1976, Božena Benešová. Praha: Melantrich.

Mold a n o vá D., 1993, Studie o české literatuře na přelomu století. Ústí nad Labem: Univerzita J. E. Purkyně.

Mold a n o vá D., 2011, Na písčitých pưdách. Praha: Agentura Pankrác.

Mold a n o vá D., 2014, Vilém Mrštík 1893. In Vilém Mrštík. Od realismu k moder$n \check{e}$, red. Jarmila Schreiberová, Praha: PNP.

M o $1 \mathrm{~d}$ a n o v á D., 2016, Legionářská literatura jako součást paměti národa. In Pamét' válek a konfliktư $V$. kongres světové literárněvédné bohemistiky, red. A. Kratochvil, J. Soukup. Praha: Ústav pro českou literaturu AV ČR, s. $203-212$.

Š a 1 d a F.X., 1953, Novina, 1908/09. In Kritické projevy 7. Praha: Československý spisovatel, s. 295-298.

Š a 1 d a F.X., 1936, Božena Benešová. „Šaldův zápisník” 8, s. 270-271.

O p e lík J., 1992, O »vídeňský« román: Žalár̆ nejtemnější. Marginálie 1988-1990, Praha: PNP s. 46

T o m á š e k M., 2006, Labyrint díla K.M.Čapka-Choda. Ostrava: Filozofická fakulta Ostravské univerzity.

vy". Editorovi a autoru poznámek ovšem lze složit kompliment za to, že nesáh k cenzurním škrtům, což byla praxe ne neobvyklá. Konec konců, kdo čte poznámky a vysvětlivky. 